\title{
Student retention in Indonesian private university
}

\author{
Yulianti Talar, Jimmy Gozaly \\ Industrial Engineering Department, Maranatha Christian University, Indonesia
}

\begin{tabular}{l} 
Article Info \\
\hline Article history: \\
Received Mar 11, 2020 \\
Revised Jun 22, 2020 \\
Accepted Jul 23, 2020 \\
\hline
\end{tabular}

\section{Keywords:}

Engagement

Satisfaction

Student confidence

Student retention

\begin{abstract}
Private universities require more effort to retain student students so that these students can complete their studies and then work in the community. Through this research, input will be given to the study program regarding the improvement that must be made so that the private university can compete with the public university and educate the nation's children. Data collection was obtained through questionnaires and observations to 209 students. Data processed by Discriminant Analysis, Crosstabulations, and Correlations Analysis dan statistical descriptive methods. Independent variables that significantly affect student retention are satisfaction with the closeness of social relationships with fellow students, student confidence to graduate on time, student confidence to get a good career after graduation, and college attendance. Study program still has to work hard to make improvements to increase satisfaction and students' engagement level.
\end{abstract}

This is an open access article under the CC BY-SA license.

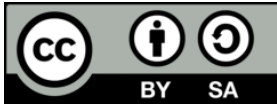

\section{Corresponding Author:}

Yulianti Talar, Industrial Engineering Department, Maranatha Christian University, Suria Sumantri 65, Bandung, Indonesia.

Email: yulianti@eng.maranatha.edu

\section{INTRODUCTION}

The role of education in one's future is no doubt; even the progress of a country will be greatly influenced by the education of the nation's children. Education should be the center of attention of all people, both families, and governments. Higher education as one of the institutions that are obliged to educate the nation has a responsibility towards students as their students; therefore the university will try to complete its responsibilities in educating students to graduates.

In 2005, Seidman said that retention is the ability of an institution to retain students from admission to graduation or completion of levels [1]. Research on retention has examined the factors that influence student retention and also validates the effect of these factors on various student populations. Atif, Richard, and Bilgin in 2013 said that most of the research on retention was conducted in the US, UK, and Europe [2], and research related to retention in Indonesia is still limited.

Data from the 2017 University Statistics Book published by the Ministry of Research, Technology and Higher Education (Kemenristek) of the Republic of Indonesia shows the number of college dropouts in Indonesia. Out of 6,924,511 students enrolled in state and private universities, $2.8 \%$ (195,176 students) dropped out, and 2.5\% (21,146 students) were students in West Java colleges. The number of students dropping out of college is getting more attention from the private universities, because the percentage of the number of students who do not continue their study at private universities is much higher than public university, which is $0.3 \%$ for public universities compared to $4.0 \%$ for private universities in Indonesia, and for West Java by $0.2 \%$ for public universities compared to $3.1 \%$ for private universities. 
Indeed, until now the interest of high school students to enter public universities is far higher than private universities because besides public universities tuition fees are considered cheaper and the quality of education at public universities is considered better so that graduates are easier to find jobs in leading companies. Maybe that is one of the reasons that makes public universities students more enduring college and graduate. Private universities require more effort to retain student students so that these students can complete their studies and then work in the community. With the high competition to get new students with public universities and other private universities, it is unfortunate if students who have been registered as students in a study program at private universities then do not complete their studies.

Many theories in college student retention research were developed from the theoretical model of persistence from Tinto, where Tinto states that persistence occurs when students successfully integrate with institutions academically and socially [3]. The integration will then be influenced by the characteristics and objectives of the pre-college, interaction with peers, faculty, and factors outside the classroom. In their 2013 research, Atif et al. said that Tinto also issued a theory about student departures that students tend to remain in the institution (which they entered) when they get clear goals for themselves and regard the institution as a powerful vehicle in achieving their goals. Jurkowitsch et al. research in 2006 stated that antecedents for student satisfaction are service performance, university performance, relationships, and university standing [4]. Maher and Macallister in their research in identified important factors for student retention, namely pedagogy, class structure, nature of assignments, institutional factors, personal factors, activities that help students feel like part of a supportive learning community (beyond lecture theater), informal student interaction with peer and academic staff [5]. Students who are involved in interactions feel valued and have a bond with the instructor, and they will be more likely to seek support and ultimately encourage their chances of success. Jensen researched the factors that influence student retention in tertiary institutions. According to Jensen, the factors that influence student retention consist of individual levels, institutional levels, and social and external levels [6]. Related to terms in retention, Atif et al. [2] identified 16 overlapping terms related to retention (for example progression, persistence, goal attainment, completion, achievement, transfer, attrition, etc.). They differentiated and made 6 categories of student retention or attrition behavior namely persister, stop-out, transfer, attainer, drop-out, and slow-down.

This research is initial research about student retention in one of the study programs at a private university in Indonesia. Furthermore, there will be further research to get a more comprehensive picture of student retention at private universities in Indonesia. Through this research, input will be given to the universities regarding the improvement that must be made so that the private university can compete with the public university and together educate the nation's children.

\section{RESEARCH METHOD}

Data used in this study were obtained through questionnaires and observations, where the case was in one of the engineering study programs at a private university in Bandung Indonesia. The independent variables adapted from studies related to previous student retention, consisting of 25 independent variables, namely:

a. The individual level is divided into two factors, namely: 1) Academic Performance, consisting of student GPA; 2) Attitudes and Satisfaction, consisting of $\%$ of college attendance, student confidence to graduate on time/graduate with a satisfactory GPA/get a good career after graduation, satisfaction levels on opportunities to interact actively in learning activities, opportunities to conduct research with lecturers, opportunities to collaborate and share experiences with other students, opportunities to discuss with the instructor, feedback provided by the instructor regarding the progress of the lecture, the benefits of the lecture material taught, the suitability of the value of the courses obtained with the effort that has been done, the function of the supporting work units on campus (ex: Student Unit, Extracurricular).

b. Assessment of Institutions, namely the pride of being a student in a study program/university, a sense of belonging to the campus and involvement with the campus community, and a sense of being needed by the campus (sense of importance).

c. Social and External Levels namely the level of parent education, satisfaction with family/lecturer/study program support to complete lectures, satisfaction with comfort on campus, satisfaction with the closeness of social relations (with lecturers and all study program staff, fellow students), satisfaction with activities social with fellow students.

The dependent variables used is a modification of the Atif, Richards and Bilgin research in 2013, where in this study the category of student retention was divided into four types as presented in Table 1 [2]. 


\begin{tabular}{|c|c|}
\hline \multicolumn{2}{|r|}{ Table 1. Dependent variable } \\
\hline Retention Type & Description \\
\hline The persister/retain/stayer & $\begin{array}{l}\text { Students who will continue their studies without disturbances, according to the curriculum set by } \\
\text { the Industrial Engineering Study Program. }\end{array}$ \\
\hline The stop-out & Students who leave the study program for a certain period and return to continue their studies (leave). \\
\hline The slow-down/part-time & Students who continue their studies but only contract a few courses per semester. \\
\hline $\begin{array}{l}\text { The transfer and drop- } \\
\text { out/leaver }\end{array}$ & $\begin{array}{l}\text { Students who leave the study program, either because they continue in another study program } \\
\text { (moved) or do not return (resign). }\end{array}$ \\
\hline
\end{tabular}

The questionnaire was used to collect data from the population that is all active students in study program, with purposive sampling technique based on the criteria of active students who have attended lectures for at least four semesters, with the consideration that the student has undergone lectures at study program long enough to be able to assess his/her retention to complete his/her studies. The questionnaire was distributed in May 2019, producing data from 209 students. The questionnaire consisted of 3 parts, namely the profile of students, the assessment of students of institutions and social and external levels and student retention:

a. Student profile to get an overview of student academic performance, behavior and family support on a nominal and ordinal scale.

b. Assessment of satisfaction, engagement with institutions and social support using the interval scale.

c. Student Retention: students choose one of the 4 retention groups that describe themselves, on a nominal scale.

The next step, each part of the questionnaire will be processed as:

a. The students' GPA, \% of college attendance and parental education level, first are processed using the Method of Successive Interval (MSI) before being processed using Discriminant Analysis, to change the scale of variables that were previously ordinal into interval scales.

b. Testing classic assumptions before processing Discriminant Analysis, followed by processing Discriminant Analysis according to the independent and dependent variables above.

c. Crosstabulation processing to calculate the relationship between student retention with GENDER variables, student force (YEAR), parental education (PARENT_EDU), sponsor of tuition financing (FINANCIAL), time spent on campus other than for college (TIME_ATTEND), time spent on campus for independent study (TIME_SELFSTUDY), for group learning (TIME_GROUPSTUDY), for non-academic activities (TIME_NONACAD).

d. Processing the correlation value to determine the relationship between the independent variables that significantly influence the dependent variable.

e. Calculating the average level of student satisfaction with institutions and the sense of student attachment to the campus.

\section{RESULTS AND DISCUSSION}

\subsection{Discriminant analysis}

Based on the Discriminant Analysis method, it was found that of the 25 independent variables processed by Discriminant Analysis, only 4 independent variables were proven to significantly influence and distinguish student retention, namely:

a. SOCIAL_REL_STUDENTS (Satisfaction with the closeness of social relationships with fellow students): Social and External Levels, Social Support Factors

b. CONF_GRAND_ONTIME (Student confidence to graduate on time): Individual Level, Attitudes Factor

c. CONF_CAREER (Student confidence to get a good career after graduation): Individual Level, Attitudes Factor

d. COLL_ATTEND (average\% of college attendance): Individual Level, Attitudes Factor

Academic Performance, Academic Engagement and Satisfaction Factors from the Individual level do not significantly influence student retention. Attitudes Factor is a factor that is very influential in student retention. The results from Discriminant Analysis have high accuracy with $88.5 \%$ classification accuracy.

The results of the Discriminant Analysis above are following the results of Nes, Evans, and Segerstorm's research that academic nature and optimism are related to motivation and adjustment, reducing dropout rates and increasing GPA [7]. The suitability of the study results was also obtained from the research conducted by Nicpon et. al., that showed the higher level of social support is associated with higher persistence [8]. Dixon Rayle and Chung also stated that the experience that other people depend on us, are interested in us, and care about our destiny will be related to persistence [9]. Martinez and Munday in Willging and Johnson through their research in the UK confirmed that students were more likely to drop out 
if they found it difficult to make friends [10]. Martinez and Munday's research results are consistent with the results of the Discriminant Analysis above. However, Martinez and Munday's statement that students are more likely to drop out if they are more dissatisfied with the quality of learning than students currently is not indicated by the results of this study because the learning quality variable does not appear as a significant variable affecting the category of student retention. The results of the Discriminant Analysis above are also not following the results of Townsend and Wilson's research conducted on predominately Caucasian students that showed social and academic integration is influenced by opportunities to research with lecturers [11]. In this study, the opportunity to research with lecturers did not appear as independent variables that significantly affect the student retention category.

\subsection{Crosstabulations analysis}

Crosstabulations are used to determine the relationship between several student profiles and student retention. The results of crosstabulations can be seen in Table 2. In the crosstabulation results above it appears that variables that have a significant relationship with student retention are YEAR and PARENT_EDU, with a significance value $<0.05$. The strength of the relationship is not too strong because the value is still not close to 1 . The conclusion of the results of these crosstabulations is following Levy's research in Dela Cruz and Quimbo which stated that the closer a student is to graduating, the more persistence he will be [12].

The results of the crosstabulations above are not following the studies of Li and Killian and Martinez and Munday. Li and Killian found that the financial status of students was an important factor determining persistence in higher education [13], but the results above did not indicate a significant relationship between student finances (indicated by funding while in college) with student retention. Martinez and Munday's research showed that male students are more likely to drop out [14] and this is not indicated by the above calculation results.

Table 2. Crosstabulations result

\begin{tabular}{lcc}
\hline \multicolumn{1}{c}{ VARIABLES } & \multicolumn{2}{c}{ Symmetric Measures: Contingency Coefficient } \\
& Value & Sig \\
\hline GENDER & 0.135 & 0.694 \\
YEAR & 0.356 & 0.034 \\
PARENT_EDU & 0.392 & 0.013 \\
FINANCIAL & 0.256 & 0.260 \\
TIME_ATTEND & 0.222 & 0.547 \\
TIME_SELFSTUDY & 0.140 & 0.981 \\
TIME_GROUPSTUDY & 0.151 & 0.963 \\
TIME_NONACAD & 0.277 & 0.139 \\
\hline
\end{tabular}

\subsection{Correlation analysis}

Correlation analysis for this study was conducted twice, to determine the strength of the relationship between the four independent variables above with student retention, namely through the value of Eta because the independent variable is interval scale and the dependent variable is nominal scale. The second correlation analysis was conducted to determine the strength of the relationship between the four independent variables with other independent variables. The Eta values based on the results of crosstabulation processing are presented in Table 3. Eta values vary from 0 to 1 , values getting closer to 1 means that the independent variable hasa stronger relationship with student retention. The table above shows that of the four independent variables, the CONF_GRAD_ONTIME variable has the strongest relationship with student retention.

Table 3. Eta values between independent variables and student retention

\begin{tabular}{lc}
\hline \multicolumn{1}{c}{ Independent Variables } & Eta Value \\
\hline SOCIAL_REL_STUDENTS & 0.218 \\
CONF_GRAD_ONTIME & 0.257 \\
CONF_CAREER & 0.026 \\
COLL_ATTEND & 0.159 \\
\hline
\end{tabular}

Calculation of the correlation value between the four independent variables above with other independent variables gives the results in Table 4. The Correlations table below shows that the SOCIAL_REL_STUDENTS and CONF_GRAD_ONTIME variables are related to quite many other variables. This information is useful for the study program when making improvements/improvements due to the correlation or relationship between these variables. 
Table 4. Correlations

\begin{tabular}{|c|c|c|c|c|c|c|c|c|}
\hline \multirow[t]{2}{*}{ Variabel } & \multicolumn{2}{|c|}{$\begin{array}{c}\text { SOCIAL_REL } \\
\text { _STUDENTS }\end{array}$} & \multicolumn{2}{|c|}{$\begin{array}{c}\text { CONF_GRAD } \\
\text { _ONTIME }\end{array}$} & \multicolumn{2}{|c|}{ CONF_CAREER } & \multicolumn{2}{|c|}{ COLL_ATTEND } \\
\hline & Corr & Sig. & Corr & Sig. & Corr & Sig. & Corr & Sig. \\
\hline OPP_INTERACT & $0.184^{* *}$ & 0.008 & $0.189^{* *}$ & 0.006 & & & & \\
\hline OPP_DISCUSS & $0.417^{* *}$ & 0.000 & $0.187^{* *}$ & 0.007 & & & & \\
\hline FEEDBACK & $0.289^{* *}$ & 0.000 & & & & & & \\
\hline COURSE_BENEFIT & $0.217^{* *}$ & 0.002 & & & & & & \\
\hline SUPPORT_UNIT & $0.302^{* *}$ & 0.000 & & & & & & \\
\hline FAM_SUPPORT & $0.245^{* *}$ & 0.000 & & & & & & \\
\hline LECT_STAFF_SUPPORT & $0.321^{* *}$ & 0.000 & $0.252^{* *}$ & 0.000 & & & & \\
\hline SOCIĀL_REL_LECT_STAFF & $0.300^{* *}$ & 0.000 & & & & & & \\
\hline SOCIAL_ACT_STUDENTS & $0.611^{* *}$ & 0.000 & & & & & & \\
\hline COMFORT_CAMPUS & $0.473^{* *}$ & 0.000 & & & & & & \\
\hline PROUD_STUDENTS_DEPT & $0.325^{* *}$ & 0.000 & $0.231^{* *}$ & 0.001 & & & & \\
\hline PROUD_STUDENTS_UNIV & $0.241^{* *}$ & 0.000 & $0.212^{* *}$ & 0.002 & $0.208^{* *}$ & 0.002 & & \\
\hline SENSE_BELONG_CAMPUS & $0.280^{* *}$ & 0.000 & $0.218^{* *}$ & 0.002 & & & & \\
\hline SENSE_INVOLVE_COMMUNITY & $0.279^{* *}$ & 0.000 & $0.215^{* *}$ & 0.002 & & & & \\
\hline SENSE_IMPORTANCE & & & $0.283^{* *}$ & 0.000 & & & & \\
\hline CONF_GRAD_GOOD_GPA & & & $0.446^{* *}$ & 0.000 & $0.245^{* *}$ & 0.000 & & \\
\hline COLL_GRADE & & & $0.412^{* *}$ & 0.000 & $-0.202^{* *}$ & 0.003 & $0.207^{* *}$ & 0.003 \\
\hline
\end{tabular}

\subsection{Descriptives Statistics}

Pascarella and Terenzini stated that negative interactions and experiences tend to decrease academic and social integration, and will cause students to withdraw [15]. Next in Table 5 is the calculation of the average level of student satisfaction of study programs. It can be seen that the average satisfaction value is around 3 (with a maximum value of 4). Institution still needs a lot of improvements to increase the level of student satisfaction. The lowest level of satisfaction is in the satisfaction of the functions of the supporting work units on campus (example: Student Unit, Extracurricular, etc.). Table 6 shows the average value of students' engagement with the institution is still low, which is below the value of 3.0 (2,885). Even though those variables do not significantly differentiate and influence student retention, the institution must still try to increase students' sense of engagement with the institution.

Table 5. Average grades of student satisfaction levels

\begin{tabular}{lc}
\hline \multicolumn{1}{c}{ Statements } & Satisfaction Level Average \\
\hline Opportunities to actively interact in learning activities. & 3.029 \\
Opportunities to conduct research with lecturers. & 2.828 \\
Opportunities to collaborate and share experiences with other students. & 3.148 \\
Opportunities to discuss with teachers. & 3.086 \\
Feedback is given by the instructor regarding the progress of the lecture. & 3.081 \\
Benefits of lecture material taught. & 3.201 \\
Conformity of the value of courses obtained with the effort that has been done & 2.923 \\
Supporting work unit functions on campus (example: Student Unit, Extracurricular, etc.) & 2.742 \\
Family support for completing college. & 3.421 \\
Support from lecturers and all study program staff to complete their studies. & 3.172 \\
Closeness of social relations with lecturers and all study program staff. & 3.110 \\
Closeness of social relations with fellow students. & 3.115 \\
Social activities with fellow students. & 3.048 \\
Comfort in the campus environment. & Average \\
\end{tabular}

Table 6. Average engagement level with institution

\begin{tabular}{|c|c|}
\hline Statements & Average Engagement Level with Institution \\
\hline I feel proud to be a student at the study program in this university & 3.110 \\
\hline I feel proud to be a student in this university & 3.096 \\
\hline I feel part of the campus & 2.890 \\
\hline I feel I have an involvement with the campus community & 2.722 \\
\hline I feel needed by the campus & 2.608 \\
\hline Average & 2.885 \\
\hline
\end{tabular}

Tinto in his writing stated 5 conditions that were considered supportive of retention, namely expectation, advice, support, involvement, and learning [16]. In this study, the authors suggest the development of supportive conditions of retention based on variables that correlate with independent 
variables that influence student retention from the data in Table 4. The suggestions are empowering lecturers to emphasize the expectations of study programs for students through feedback given by the lecturer regarding the progress of the lecture (FEEDBACK). Lecturers can convey their expectations regarding the outcomes of the courses they teach so that students are demanded to meet these expectations. Lecturers are also asked to deliver clear and consistent information related to individual course goals and course objectives on an ongoing basis for the ability of students and their careers in the future (COURSE_BENEFIT).

Students need to be supported in academic, social, and personal fields, according to their individual needs. Many variables related to the development of supportive conditions, namely through the support of lecturers and all study staff programs to complete their studies (LECT_STAFF_SUPPORT) through the willingness of lecturers to serve student consultation and good service from study program staff. This support becomes very important; DeFeo's study stated that students who need the help most often do not ask for it [17]. Nemko advised universities to assign peer mentors to each new student, where the mentor is a successful junior, who accompanies new students at least the first 2 years [18]. Research by Nora and Crisp suggested that there is a relationship between mentoring and persistence, mentoring studies conducted between faculty-students or students will help students feel more comfortable in the lecture environment [19]. Support is also needed for non-academic activities, namely supporting work units on campus that function well (for example Student Units, Extracurricular, etc.) (SUPPORT_UNIT) with activities that support student development in non-academic and organizational experience, family support for completing college (FAM_SUPPORT), and comfort in the campus environment (COMFORT_CAMPUS) by creating a safe and comfortable campus. The study program needs to focus more on increasing the level of satisfaction in supporting work units on campus because it has the lowest satisfaction value (see Table 5).

To develop involvement, students must be involved as valuable institutional members through opportunities to connect with faculty, staff and other students, both in academic activities such as through collaborative seminars or non-academic activities such as coffee morning activities together (Opportunity to actively interact in learning activities) and opportunities to discuss with teachers/OPP_INTERACT and OPP_DISCUSS, and Social relations with lecturers, all study programs staff and fellow students/ SOCIAL_REL_LECT_STAFF and SOCIAL_ACT_STUDENTS.

Tinto also gave more emphasis on the condition of learning. He said that students who spend more time working on assignments, especially with other students will learn more and will endure more [16]. To build learning communities, one of them can be arranged for students to work together in groups. Tinto et al. research stated that students who make their self-supporting groups will spend more time together, and as a result student will learn more and learn better together. They will be involved academically and socially, then the persistence will increase [20].

To increase student's pride on campus and study programs (PROUD_STUDENTS_UNIV and PROUD_STUDENTS_DEPT), it is necessary to strengthen the institution's brand. Toma J. D.'s research results showed that attachments between institutions and students can be formed by forming an effective college brand [21]. Palacio et. al state that the higher students' attachment to an institution, the student's commitment and student's satisfaction with the institution will also increase [22]. Park et. al even states that students can form and maintain bonds throughout school until after they graduate [23]. Therefore, it is very important to strengthen the college brand to increase engagement between students and institutions because PROUD_STUDENTS_UNIV and PROUD_STUDENTS_DEPT have a strong correlation with SOCIAL_REL_STUDENTS, students' confidence to graduate on time (CONF_GRAD_ONTIME) and confidence to get a good career after college (CONF_CAREER) which is an independent variable that significantly influences student retention.

The study program also needs to increase the level of student confidence to graduate with a good GPA (CONF_GRAD_GOOD_GPA) because an increase in the level of confidence will increase CONF_GRAD_ONTIME and CONF_CAREER which significantly influences student retention. Ghosh et al. research defined trust as the degree to which students are willing to rely on or have faith and trust in universities to take the right steps that benefit them and help them achieve learning and career goals [24]. The research results of Dennis et al. showed that trust in institutions is significantly influenced by the brand image [25]. Hemsley-Brown \& Oplatka's research [26] and Nguyen \& LeBlanc's research [27] stated that images play a large role in market positioning. Based on those researches, Ivy suggested universities need to make adjustments to image and positioning strategies in the market analysis [28].

Further research needs to be done to increase students' engagement level with the institution, because the sense of being part of the campus (SENSE_BELONG_CAMPUS), involvement with the campus community (SENSE_INVOLVE_COMMUNITY) and feel needed by the campus (SENSE_IMPORTANCE) have a low average value (See Table 6). Those three variables are strongly correlated with SOCIAL_REL_STUDENTS and CONF_GRAD_ONTIME, which significantly influence Student Retention. Walton and Cohen's research (2007) showed students who feel they are not part of the campus feel that they 
are in the wrong place, which then leads to withdrawal and subsequently reduces motivation to stay on campus [29]. Hurtado \& Ponjuan research [30] and Stebleton et al. research [31] stated that a sense of belonging can emerge from previous student experiences, but is strongly shaped by the broad campus climate and perceptions of campus ownership formed from their daily interactions with other students, faculty, staff, and administrators on campus, also through the messages felt by the interaction for them. In his research, Tinto states that a sense of belonging is not only a reflection of students' perception of their existence in the social environment but also a reflection of students' academic belonging. Sense of academic can be broken when students find that their academic interest is not supported by the institution [32].

\section{CONCLUSION}

The research sample consisted of 182 Persisters, 20 Slow Downs, 3 Stop Outs, 4 Leavers, which means that out of 209 respondents, 202 students plan to study until graduation. Not all the results of this study are following the results of previous studies, and this may occur due to differences in the students' characteristics and universities. For this study, the independent variables that significantly affect student retention are satisfactied with the closeness of social relationships with fellow students, student confidence to graduate on time, student confidence to get a good career after graduation, and college attendance. Student satisfaction with the closeness of social relationships with fellow students and student confidence to graduate on time has the strongest relationship with student retention. The average level of student satisfaction is still at 3.0 and the average value of students' engagement with the institution is below 3.0, which means the study program still has to work hard to make improvements to increase satisfaction and students' engagement level.

As a proposal, some variables that can be used to build supportive conditions of retention are feedback given by the lecturer regarding the progress of the lecture, lecturers convey clear and consistent information related to their future course and career goals, support of lecturers and all study program staff to complete their studies, supporting work units on campus that function well (for example Student Units, Extracurricular), family support for completing colleges, comfort in the campus environment, opportunities to actively interact in learning activities and opportunities to discuss with teachers, and social relations with lecturers, all study programs staff and fellow students. The institution also needs to strengthen the institution's brand and make adjustments to image and positioning strategies in the market analysis.

This research is preliminary research to get a comprehensive picture of student retention at private universities in Indonesia. To complement this research on student retention, further research needs to be done related to brand improvement, adjusting the brand image and positioning of the institution in the eyes of the public, as well as research related to improving students' sense of belonging.

\section{ACKNOWLEDGEMENTS} this research.

Researchers would like to thank Maranatha Christian University Bandung for fully funding

\section{REFERENCES}

[1] Seidman, A., College Student Retention: Formula for Student Success, Westport, Connecticut: Praeger, 2005.

[2] Atif, A., Richards, D., and Bilgin, A., "A Student Retention Model: Empirical, Theoretical and Pragmatic Considerations," Conference Paper for $24^{\text {th }}$ Australasian Conference on Information Systems, pp. 1-11, 2013.

[3] Tinto, V., "Dropouts from higher education: a theoretical synthesis of recent research," Reviewof Educational Research, vol. 45, no. 1, pp. 89-125, 1975.

[4] Jurkowitsch, S., et al., "A student satisfaction model for Austrian higher education providers considering aspects of marketing communications," Innovative Market, vol. 2, no, 3, pp. 9-23, 2006.

[5] Maher, M. and Macallister, H., "Retention and Attrition of students in higher education: challenges in modern times to what works," Higher Education Studies, vol. 3, no. 2, pp 62-73, 2013.

[6] Jensen, U., "Factors Influencing Student Retention in Higher Education" Summary of Influential Factors in Degrees Attainment and Persistence to Career or Further Education for At-Risk/High Educational Need Students, Pacific Policy Research Center, Honolulu: Kamehameha School, Research \& Evaluation Division, 2011.

[7] Nes, L.S., Evans, D.R., and Segerstorm, S.C., "Optimism and college retention: mediation by motivations, performance, and adjustment," Journal of Applied Psychology, vol. 39, no. 8, pp. 1887-1912, 2009.

[8] Nicpon, M., Huser, L., Blanks, E., Sollenberger, S., Befort, C., and Kurpius, S., "The relationship of loneliness and social suppport with college freshmen's academic performance and persistence," Journal of College Student Retention: Research, Theory and Practice, vol. 8, no. 3, pp. 345-358, 2007.

[9] Dixon Rayle, A. and Chung, K., "Revisiting first year college students' mattering: social support, academic stress and the mattering experience," Journal of College Student Retention: Research, Theory and Practice, vol. 9, no. 1, pp. 21-37, 2008.

Int. J. Eval. \& Res. Educ. Vol. 9, No. 3, September 2020: 486 - 493 
[10] Willging, P.A. and Johnson, S.D., "Factors that influence students' decision to dropout of online courses, Journal of Asynchronous Learning Networks, vol. 13, no. 3, pp. 115-127, 2009.

[11] Townsend, B. and Wilson, K., "The academic and social integration of persisting community college transfer student," Journal of College Student Retention: Research, Theory \& Practice, vol. 10, no. 4, pp. 405-423, 2009.

[12] DelaCruz, R. and Quimbo, M., "Persistence, retention and completion of BS agriculture students in the university of the Phillipiner," Pertanika Journal of Social Sciences \& Humanities, vol. 27, no. 12, pp. 223-232, 2019.

[13] Li, G. and Killian, T., "Students who left college. an examination of their characteristics and reasons for leaving," AIR Forum Papers, (ERIC ED 433779), 1999.

[14] Martinez, P. and Munday, F., "9000 voices: Student persistence and dropout in further education (FEDA Report Vol. 2 No. 7)," London, UK: Further Education Development Agency (ERIC Document Reproduction Service No ED 427169), 1998.

[15] Pascarella, E. and Terenzini, P., How college affects students: findings and insights from twenty years of research, San Francisco, CA: Jossey-Bass, 1991.

[16] Tinto, V., Taking student retention seriously, Syracuse University, 2007.

[17] DeFeo, D.J., Bonin, D., and Ossiander-Gobeille, M., "Waiting and help-seeking in math tutoring exchanges," Journal of Developmental Education, vol. 40, no. 3, pp. 14-22, 2017.

[18] Nemko, M., "Easy ways to improve a college's retention rate," Chronicle of Higher Education, vol. 54, no. 43, pp. A30, 2008.

[19] Nora, S. and Crisp, G., "Mentoring students: conceptualizing and validating the multi-dimensions of a support system," Journal of College Student Retention: Research, Theory \& Practice, vol. 9, no. 3, pp. 337-356, 2008.

[20] Tinto, V., Engstorm, E., Hallock, H., Riemer, S., "Learning Communities in Higher Education," Higher Education in the United States: An Encyclopedia, Santa Barbara: ABC-CLIO Publisher, 2001.

[21] Toma, J. D., "Positioning for presige in Amerika higher education: case studies of strategies at four public institutions toward "getting to the next level," Conference of Association for the Study of Higher Education, 2008.

[22] Palacio, A. B., Meneses, G. D., and Perez, P. J. P., "The configuration of the university image and its relationship with the satisfaction of students," Journal of Educational Administration, vol. 40, no. 5, pp. 486-505, 2002.

[23] Park, C. W., MacInnis, D. J., Priester, J., Eisingerich, A. B., and Iacobucci, D., "Brand attachment and brand attitude strength: conceptual and empirical differentiation," Journal of Marketing, vol. 74, no. 6, pp. 1-17, 2010.

[24] Ghosh, A. K., Whipple, T. W, and Bryan, G. A., "Student trust and its antecedents in higher education," The Journal of Higher Education, vol. 72, no. 3, pp. 322-340, 2001.

[25] Dennis, C., Papagiannidis, S., Alamanos, E., and Bourlakis, M., "The role of brand attachment strength in higher education," Journal of Business Research, vol. 69, no. 8, pp. 3049-3057, 2016.

[26] Hemsley-Brown, J. and Oplatka, I., "Universities in a competitive global marketplace: a systematic review of the literature on higher education marketing," International Journal of Public Sector Management, vol. 19, no. 4, pp. 316-338, 2006.

[27] Nguyen, N., LeBlanc, G., "Image and reputation of higher education institutions in students' retention decisions," International Journal of Educational Management, vol. 5, no. 6, pp. 303-311, 2001.

[28] Ivy, J., "Higher education institution image: a corresspondence analysis approach," International Journal of Education Management, vol. 15, no. 6, pp. 276-282, 2001.

[29] Walton, G. and Cohen, G., "A question of belonging: race, social fit, and achievement," Journal of Personality and Social Psychology, vol. 92, no. 1, pp. 82-96, 2007.

[30] Hutardo, S., Ponjuan, L., "Latino educational outcomes and the campus climate," Journal of Hispanic Higher Education, vol. 4, no. 3, pp. 235-251, 2005.

[31] Stebleton, M., Soria, K., Huesman, R. Jr., and Torres, V., "Recent Immigrant students at researach universities: the relationship between campus climate and sense of belonging, Journal of College Student Development, vol. 55, no. 2, pp. 196-2-2, 2014.

[32] Tinto, V., "Through the eyes of students," Journal of College Student Retention Research, Theory \& Practice, vol. 19, no. 3, pp. 254-269, 2017. 